\title{
Evolution of Back Lane Design: A View of Terrace Housing in Malaysia
}

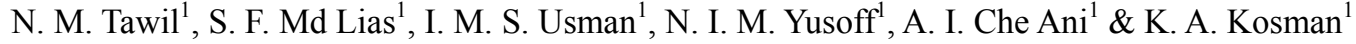 \\ ${ }^{1}$ Faculty of Engineering and Built Environment, Universiti Kebangsaan Malaysia, Bangi, Malaysia \\ Correspondence: N. M. Tawil, Faculty of Engineering and Built Environment, Universiti Kebangsaan Malaysia, \\ Bangi, Malaysia. E-mail: nmtawil@gmail.com
}

Received: May 26, 2013 Accepted: August 27, 2013 Online Published: October 29, 2013

doi:10.5539/ass.v9n15p277 URL: http://dx.doi.org/ass.v9n15p277

\begin{abstract}
Narrow roads between rows of buildings used as public paths or commonly known as back-lane; the streets neglected by most of people. The unfavorable lane in residential area indeed had existed thousand years ago since the world urbanization. This paper traces the evolution of back lane design particularly in terrace houses in Malaysia, the largest housing type built since colonization and Post World War of more than 40 years ago. The first part provides an overview on the global development tracking back from the Prehistory to Post Modernism. Secondly, it assesses six aspects of evolution through observations approach carried out in two states, Selangor and Negeri Sembilan. Critical review is made focusing on the two major elements, back lane physical design and its function with cross reference to literature research and current global issues. Variations of back lane have been discovered particularly in road width, drain condition, pavement material, landscaping, infrastructure and safety elemts.
\end{abstract}

Keywords: back lane, evolution, terrace housing, Malaysia

\section{Introduction}

Back lane or alley is often associated with annoying, disgusting, narrow and dark condition. It is the street between row of houses which are commonly under-appreciated by residents and community. Looking from Martin (2000) and Beasley (1997) point of view, back lane in residential area is characterized a matter of misplaced and out of time. It is a wasteful, unattractive, ugly, and inconsistency in the layout. As describe by among the greatest Architect, Frank Lloyd Wright had decreed residential back lane to be wasteful and insightly anachronisms row. (Wright, 1916).

Grady Clay (1980) in his outstanding research books describing United States cities defined;

Back lanes, whether in a commercial downtown area or a residential neighbourhood, are public spaces in private location. The have often become forgotten spaces about which no one seems to care, which is what attracts problems. (Clay, 1980).

Recently, in America and Canada back lane or back alleys have been indicated by New Urbanists for their ability to revive pedestrian activities throughout neighborhoods (Zelinka \& Beattie, 2003). Current New Urbanist models reintroduce the alley as an important element of residential design to help recreate the street as a live hood social space. (Hess, 2008).

Back lane in residential housing in Malaysia as similar as experienced by other develop countries, undoubtedly seen as wasteful and disgusting area. Although the issues had been written up vividly in America and Canada, it had been less discussed in South East Asia particularly in Malaysia. Perhaps it is still remain to be less considered as unnecessary and unimportant; a minor urban topics to be discussed and remain under-researched. Nevertheless back-lanes in terrace housing shall be appreciated by dwellers as an extra socio-spatial area where neighbourhood spiritual fostering and family bonding ties.

In Malaysia, Back Lane Planning Guidelines 2012 set by the Federal Department of Town and Country Planning Peninsular Malaysia, Ministry of Urban Wellbeing, Housing and Local Government (JPBD, 2012), outlining the back lane as emergency routes for fire escape. It is commonly used for utilities and infrastructure route such as telephone service, maintenance of sewerage, drainage and garbage collection. In Malaysia, laws provision regard to back-lane is stated in (1) Road, Drainage Dan Building Act 1974 (Act 133), (2) Laws of the Uniform Building 
(UBBL) 1984 and (3) Town and Country Planning Act 1976 (Act 172).

\section{Background}

\subsection{Urbanization: Prehistory to Post Modernism}

\subsubsection{Prehistory}

Variation of its function and physical design of back-lane features had changed according to urbanization and technology. Global issues play role towards the evolution of back-lane as early as before centuries (BC). The existence were identified and explored since ancient civilization town planning. History of urbanization and back lane can be found in the community's settlement from 5000 years ago in Mesopotamia and Ancient Greek. The first town was identified having back lane was Kahun or El Kahun near to Giza in 3000BC where row of houses were built for labors and workers during the period of pyramid construction. According to S. Kostof (1992), the Kahun town was laid on grid system consisting large houses surrounded by small houses.

Apart from ancient Egyptian, several rows of terrace houses being built in town named Chang'an or Xian, the capital city of the central Chinese province of Shaanxi during remarkable Tang Dynasty in China. As stated by H. Gua \& C. Ryan (2007) nowadays back-lane in Beijing Old Town or known as hutong; a kind of ancient alley or are in fact passageways formed by many closely arranged quadrangles of different sizes are still remain and waiting to be validate for hutong tourism industry.

\subsubsection{Modernism}

London Grosvernor Square designed by Nicholas Barbon was the first terraced house built in England after The Great Fire of London in 1666. Later, Architect Georgian John Woods designed and built famous terrace house at Bath; The Royal Crescent in 1767-1777 during the Industrial Revolution. Throughout the time, terraced houses built were designed for reputable classes and nobility group of people. The house design as similar as fortress which huge and spacious built up area. All units surround a garden square and plaza in the central as the centerpiece of the plan and thus back lane did not even exist.

The existence of a back lane was directly attributable to the construction of terrace houses in the growth of Industrial Revolution broke out in England at the end of the $18^{\text {th }}$ century. It was dated back to the discovery of innovative Abraham Darby cast-iron rails in 1767. Various industries had been growing rapidly since the discovery which includes manufacturing, agriculture, automotive and textile industry. In the early of Victorian period when the industrial was booming, terrace houses were built by repeating same design and joined together forming row of houses. Back-lanes in terrace housing were found in England when row of row of houses built during expansion of textile industry (Frampton, 1992).

At the beginning of the $19^{\text {th }}$ century, large cities in Lancashire District particularly in Manchester, Liverpool and to include entirely Greater London, rows of houses widely built by factory owners in large numbers in small plot with minimum construction cost. As there were in Soho, residential housing built in year 1756 in the heart of London, the density of type design of Georgian is 70-90 units per hectare was built on 4.5 meter x 6 meter (15' $x$ 20 ') plot of land. (Mead, 2007) It was built in close proximity to factories; walking distance without relying on any transportation due to inefficient system at the time.

Back-lane prominently used as communal area shared between residents. Water piping and sewerage system were channeled through back-lanes of houses. Obviously the sanitary system and wash basin which well placed in the back-lane were shared by the other inmates within the row. Population and accommodation of workers settlement were too dense with high density causes many problems to residents. Poor ventilation and lack of natural lighting penetrate to each houses were common problems faced by the community. This led to unsupervised garbage collection, blocked drains and thus flooding leading to infectious epidemic diseases namely tuberculosis and cholera which hit England and Europe in 1830-1840. The situations created huge impact and awareness to the local authorities about importance of health and maintenance of high-density settlements. (Frampton, 1992) At the end of the $19^{\text {th }}$ century, the majority and most of the lower and middle class housing English people inhabit terrace housing (Muthesius, 1982). Residential terraced housing became the most widely built up until World War II broke out. 


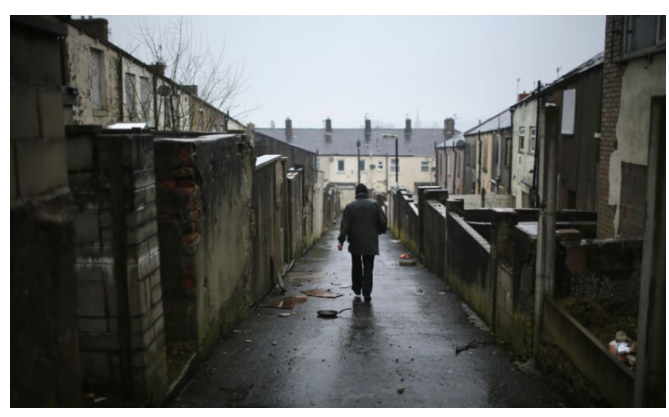

Figure 1. Back lane in Woodnok, Lancashire

Back lane separating two rows of terraces in Woodnook, Lancashire industrial town. It was among the earliest massive construction workers housing strongly influenced by the impact industrialisation in $18^{\text {th }}$ and $19^{\text {th }}$ centuries. (Source: Daily mail)

Apart from urbanization in England, American cities had undergone modest growth. As written by K. Frampton (1992) from his intense research on urban development 1800-1909 stated population in New York grew from its 1801 population of 33000 to 500000 by 1850 and 3.5 Million by 1901 .

Urban design in the form of systematic grid pocket is the most effective ways in lining and arranging high densities. Such area increase the number of back-lane or small alleys; famous word used widely by Americans, as in most large cities in the United States. Large-scale migration of population from Europe to North America in 18th century during the Industrial Revolution incorporating the urban design concepts to America. The first back-alleys in America was found and developed in Philadelphia, one of the earliest cities in Pennsylvania in 1787 (Beasley, 1997). As in New York, back-alleys are used as carriage route by homeowners. It was hidden and not be seen by the public. During the initial formation, terraced houses occupied only by noble group and aristocrats.

In the aftermath of the American Revolution, the industrial people dominate most of the urban area. Terraced houses occupied by middle and lower-class workers. It was started when the black community brought from Africa to the America and monopolized most of houses and transformed to low-class workers community residential. Back alley almost forgotten when extensive crime rate cases occurred due to its condition of narrow, dark and quiet.

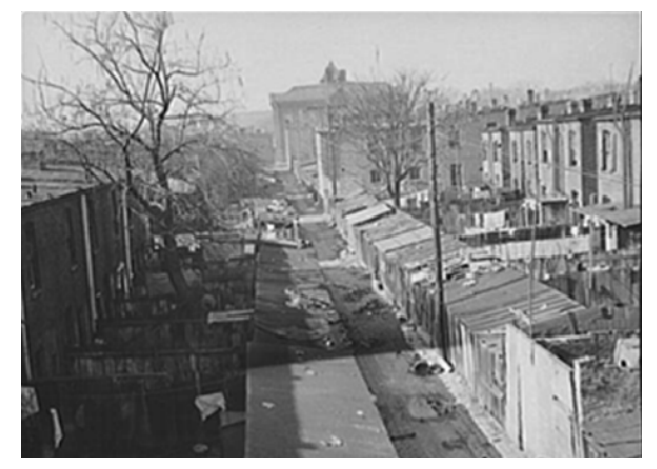

Figure 2. Back lane in Washington DC in 1941 (Cook, 1998)

The lane is surrounded by slum area and immigrants.

\subsubsection{Post Modernism}

In late of $20^{\text {th }}$ centuries the construction of terraced housing in England decreased due to thousands houses available. In 21 st Century terraced houses are only allowed to be built on low-density areas approximately 30 unit per hectare as indicated in UK Planning Policy Statement 3 (PPS3, 2006) (AJ, 2007). Back-lane serves as an emergency and escape route which originally allow vehicle to park in the garage at the back yard; was no longer used. (Armitage \& Smithson, 2007). 
Back-lane in residential areas resulted growth in crime rate. As a result it has been removed from the planning policy as enforced in year 2001 by the Planning Department to avoid criminal incident. It is part of the requirement in terrace housing scheme that small garden to be located bordering to their neighboring lots while bicycle track or paths and open spaces to be provided in front of the residence (USP 07, 2001). Absenteeism of back lane rediscovered in modern contemporary design of terrace housing scheme in United Kingdom as similar as the early stage of the first construction of terrace houses in 1970s.

Similarly as United Kingdom, United States terrace housing and the back lane same situation. Terraced houses were less built and yet replaced with detached houses in Iowa, Canada. Back-alleys were essentially eliminated from American residential planning in the 1930s (Martin, 2002). It is seen as a neglected area, vernacular architecture and the history of the material remains. (Corbett, 2002)

Currently New Urbanists attempted to restore a measure of the back-alley's social connectivity by creating some type of backyard-accessible commons, having recognized the limitations of public streetscapes as safe, defensible neighborhood social space in contemporary life.

In addition, government giving effort in contributing for alley greening programs in seven cities in the United States under sustainability planning. Most alley greening programs are narrowly oriented toward storm water management and developing integrative sustainability programs around alleys. One innovative strategy emerging among cities including Chicago, Baltimore, and Los Angeles is to green (or, in the case of Baltimore) long neglected back alleys to achieve a suite of ecosystem service and public health goals. (2012)

\subsection{Scenario in Malaysia}

Housing design in Malaysia particularly in urban areas had undergone significant changes. Housing construction on large scale in the form of terraced houses had been introduced to fulfil demand on increasing population towards city centre. The design mainly influenced by British during colonial period. Independence and formation of Malaysia 1963 created peaceful and harmonious life between different races, religions and cultures. Significant changes in the evolution of terrace housing in Malaysia took place in 1970. The main factor increasing the number of terraced housing in 1970s in the era of the New Economic Policy (NEP) which presented and implemented under the leadership reins of Prime Minister Malaysia, Tun Abdul Razak. The policy goal is to eradicate poverty and increase income of household population by providing employment opportunities in the cities. Migration of young people to the city began when the federal government established a legal system and administration in capital city of each state. Many young adults from village were requested to fill vacancies for majority government offices located in the major cities.

Several and various physical characteristics of back-lane were identified according to the Local Authority and year built. The main purpose behind constructing back-lane through the time was as utility lines and circulation. It is used as route sewerage system. The function was as similar as back lanes in English terrace housing built in late 18th and 19th centuries. Later in early of 1970s large scale of construction of terrace house built at Klang Valley to cater high demand of housing for population due to migration adapted from the pattern of industrial city in England.

Terrace housing typology in Malaysia was typically Georgian design of the colonial era. It has undergone significant changes since 1960 until 1980 as a consequence of rural migration to the urban in the 1970s. It was the promulgation of the New Economic Policy (NEP).

The housing correspond as impact to the globalization and foreign direct investment (FDI) stated by government foreign investors from industrialized country such as from United Kingdom, United States, Germany and Japan were investing manufacturing plants in electrical and electronics factories. Malaysia was chosen due to its cheap labors and low cost production. Migration of rural population to urban mass occurred in the 1970s and satellite cities were beginning to take shape. According to S. Y. Ju and S. A. Zaki (1992), the earliest terraced houses were built in Section 17, Petaling Jaya. In the 1970s until the 1980s, terrace houses were dominating the region of Petaling Jaya. It was the first satellite city in Malaysia, as the government's strategy to spread administration planning to Klang, by linking the central administrative area of the city of Kuala Lumpur and Shah Alam. Housing Trends terrace followed in Subang Jaya, Ampang, Bangi, Johor Bharu, Seremban and other cities in Malaysia in the early 1980s (Seo, Zaki \& Yun, 2011). Terraced house in the city is the most preferable and favourite choices due to its affordable price for middle income groups. As recorded by Department of Statistics Malaysia, in 2005, terrace housing grew 50\% within 10 years. In 1991 it is recorded 1074000 numbers units of terrace houses increase to 1808929 in 2000 (Department of Statistics, 2005) 
Table 1. World-wide urban development in centuries

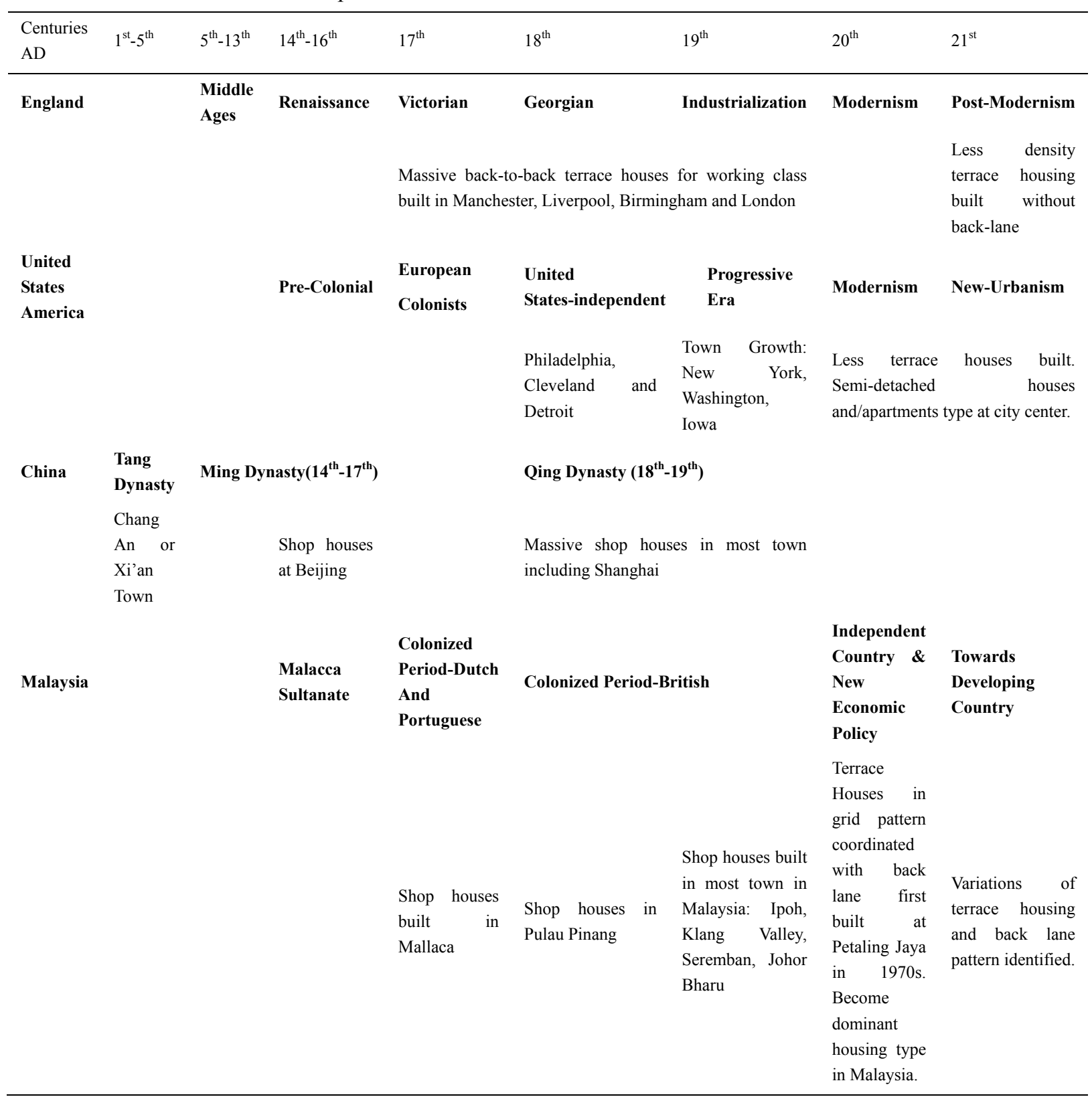

As shown in Table 1, History of terrace housing associated with back lanes in global development throughout centuries.

\section{Methodology}

The main steps of this study methodology consists of:

1) Review of history, planning and literature that is related to urbanization development. The aim is to identify the original and predeccent related to urban residential form. The outcomes of this process are according to countries and area related to each period and movement.

2) Identifying design elements-The aim is to note major design concepts within the results of the first step. This second step looks for design and function within the site observations.

3) Evolution recognition-to find relationships among the physical design element, function and global urban issues throughout 40 years terrace housing development in Malaysia. 


\section{Result and Discussion}

\subsection{Road Width}

Design elements and back-lane function evolved through urbanization and global change issues. Comparison examined from the width size, landscaping, condition of drains, pavement material and lighting system. Based on Back lane Guidelines from Department of Town and Country Planning (JPBD), back lane should be provided as maintenance walkway with asphalt or concrete pavement with varying width of 6.1 meters (20 feet), 4.6 meters (15 feet) and 3.04 meters (10 feet). (JPBD, 2012).

From observation had been taken out at Ampang, Selangor and Seremban, Negeri Sembilan, the average width of the back lane is 1.5 meters ( $5 \mathrm{ft}$.). Figure 3 and Figure 4 below shows back lanes width at selected two areas, in Ampang, Selangor and Seremban, Negeri Sembilan. Both housing scheme were built during the mass-production terrace houses in early 1980s.

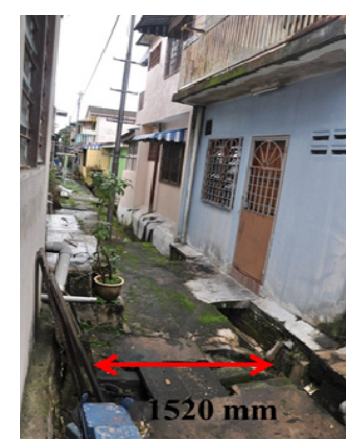

Figure 3. Back lane in Ampang, Selangor. (Author, 2013)

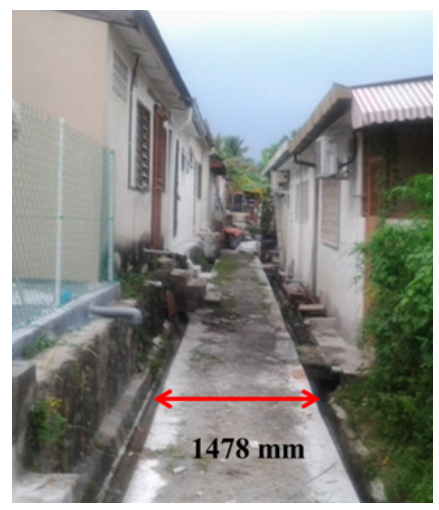

Figure 4. Back lane in Seremban, Negeri Sembilan. (Author, 2013)

Comparison made with housing scheme built in year 2008 and 2010 in Bangi, Selangor and Nilai, Negeri Sembilan. Clear width of the back lane had been measured. Figure 5 and Figure 6 below shows clearly the physical design width of the back lane is varied according to the municipal council of each area. (Source: Author, 2013)

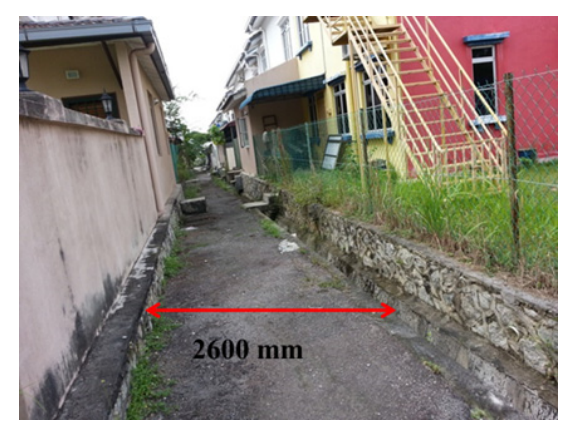

Figure 5. Housing terraces in Bangi, Selangor completed in 2008. 


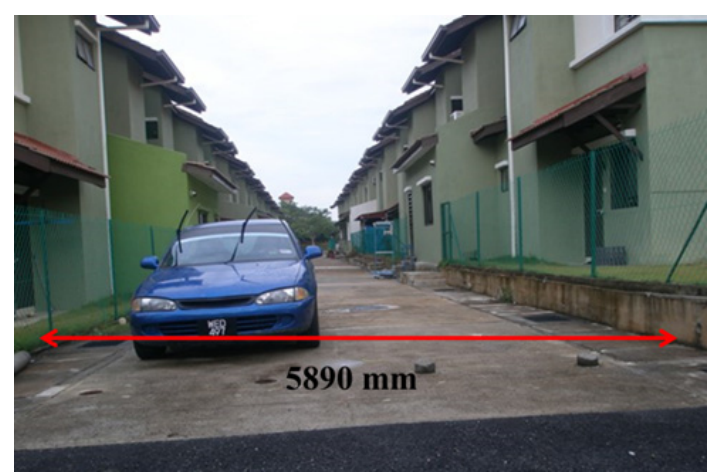

Figure 6. Housing terraces in Nilai, Negeri Sembilan completed in 2010.

\subsection{Green Elements Landscaping}

Global warming issues leads to the issue of Sustainable Living were greatly debated in the early 90's. Garden City began to gain attention by local government and the development of Putrajaya started to take shaped. (Shafii, 2006). Soft landscaping elements in the back-lane began spread over in the late 1990s. Beginning in 1998 handful of developers took the initiative incorporating green space by providing pedestrian and cycling in the back-lanes. It was also seen as an element of attractions for buyers in gated communities and luxury medium cost especially in premiums area such as Setia Alam and Glenmarie in Selangor. Figure 7 and Figure 8 shows two examples of housing scheme having landscape pocket at back lanes.

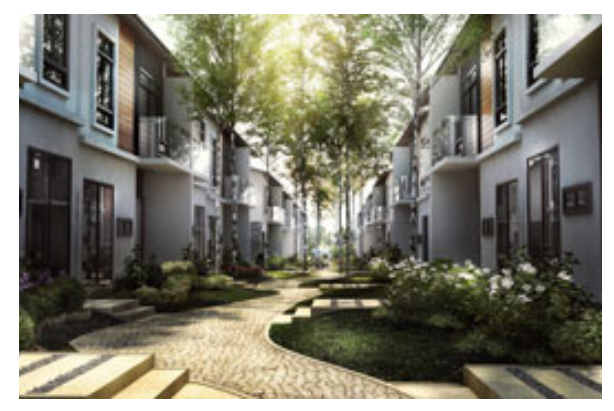

Figure 7. Artist impression of greener back lane in exclusive terrace housing in Selangor proposed by Setia Alam Group. (Source: setiaecogardens.com.my)

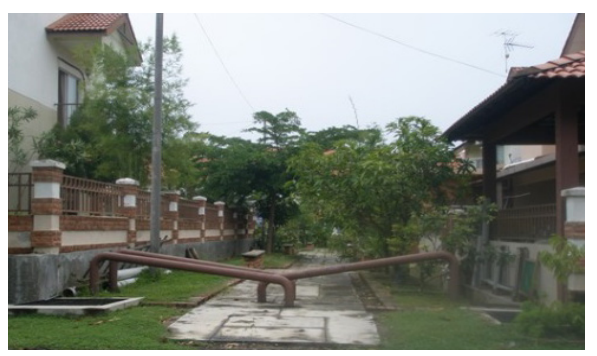

Figure 8. Green elements are added at back lane by developers in Nilai, Negeri Sembilan. (Source: Author, 2012).

\subsection{Drainage Condition}

Despite of the security, safety of dwellers to be prioritizes. Back in 1980s and 1990s, drains in the terrace residential areas uncovered and exposed to large size debris and prone to danger especially to children. Currently it is safer to occupants in closed covered drains. Dwellers can have the back lane as second exit as well as extra land to park their cars as they have limited area at front. Moreover, most of urban dwellers are having more than one car for each household. In some cases only a single car able to be park at the porch. Furthermore, the back lane could be used by residents especially for certain occasion held at their house without bothering the safety aspects. 


\section{Road Material}

Conventional construction road pavement using bitumen and asphalts required maintenance at least every five years based on the inability of the material to hold water (Hunter, 2000). In order to have less maintenance, concrete pavement with the strength and high resistance preferred as an alternative construction material in back-lanes of the new housing constructed after year 2000. Observations carried out in Nilai District, Negeri Sembilan discovered back-lane with concrete bicycle track blended with pockets of land and drains on both sides. (Figure 8)

\subsection{Infrastructure and Maintenance Routes}

Sewerage pipelines in all terraced housing in Malaysia are well structured hidden and concealed underground in the back lane. This feature was used as early history of its formation in England. Back lane in terrace housing constructed in 1980s to 1990s mainly was to served infrastructure sewage pipelines and cabling route.

Observations made at several areas discovered communication telephone poles were erected at most of back lanes. In the era of millennia where world of technology taking place, conventional telephone cable are replaced with fibre-optic communication cable. It is smaller in size and connected via underground passage. Comparison made in a back lane row of terraced houses built in 1993 (Figure 9) and housing constructed in 2010 (Figure 10). All the utility services such as electricity, telephone cablings and drainage systems are concealed underground. As a result, the back lanes are more widen physically safe and become functional place for residents.

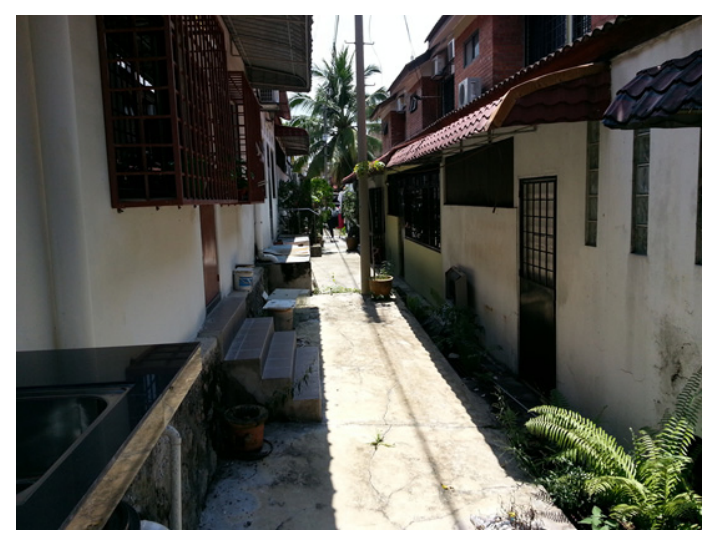

Figure 9. Housing terrace built in Kajang, Selangor in 1993. Cable and telephone poles were set up in back-lane. (Source: Author, 2012)

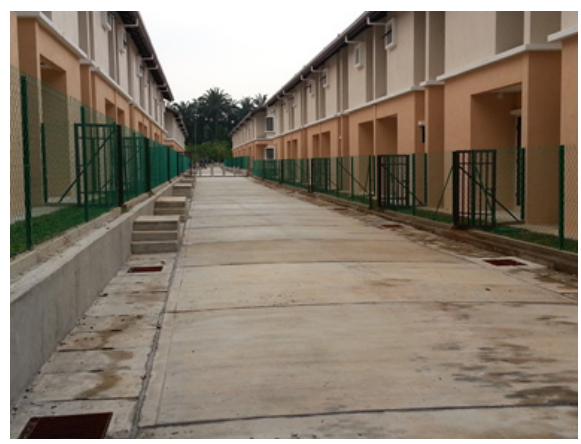

Figure 10. Housing built in 2010 in Seremban, Negeri Sembilan. Drains and utility services were closed up in back-lane constructed with concrete path. (Source: Author, 2013)

In the early 1980s, garbage was collected at the rear of houses but does not allow vehicles due to narrow lane. As mentioned by Yahaya (2005) garbage collection by transportation via back-lane were only identified when the issue of hygiene and contagious disease outbreaks in 1980s-1990s. Consequently most garbage collection services are conducted through front of the houses by building up specific design refuse chamber. It is part of local authority requirements to build refuse chamber for each unit for housing scheme constructed in the late 1990s to recent. As example, Seremban Municipal City Council (MPS) giving out sizeable refuse bin to home 
owners for houses built without refuse chamber to facilitate removal and garbage collection to be more efficient, neat and clean.

\subsection{Safety Zone}

Urbanization encourage crimes as the rate of crime is higher in large cities and in urbanized areas, urbanization increases so does crime (Gumus, 2004). Crime prevention measures will become more important in urban areas in years to come. In urban life, safety and security are the most priority aspects taken seriously by community to have safer and secured living environments. Crimes and robberies cases increase year by year in housing estate. In most of the cases, robbers are taking advantage of back lane as their access to their targeted house. Dwellers feel anxious, unsafe and no self-belonging even though in their own house. Crime rate happened twice especially during festive seasons and public holiday even weekends when residents are off from their homes. In order overcome the situation and to prevent unwanted crime to be occurs, gate is built to block the lane from public trespassing. (Figure 11)

The concept of Safe City Programmed had been introduced by Department Town Planning (JPBD) in 2004 when the government foreseen on action towards crime prevention. One of the measurements proposed by the government is by illuminating the dark areas of robbers or criminals target. Petaling Jaya Municipal Council (MBPJ) took the initiative to build a lighting system LED system illuminates the lane back to back terrace house in Petaling Jaya in 2012. (The Star, 2012). (Figure 12)

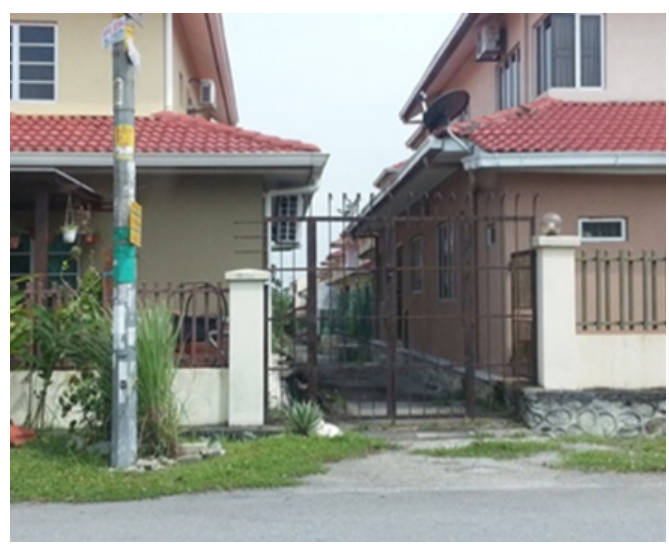

Figure 11. Gate was built by residents to avoid public trespassing Bukit Makhota, Selangor. (Source: Author, 2013)

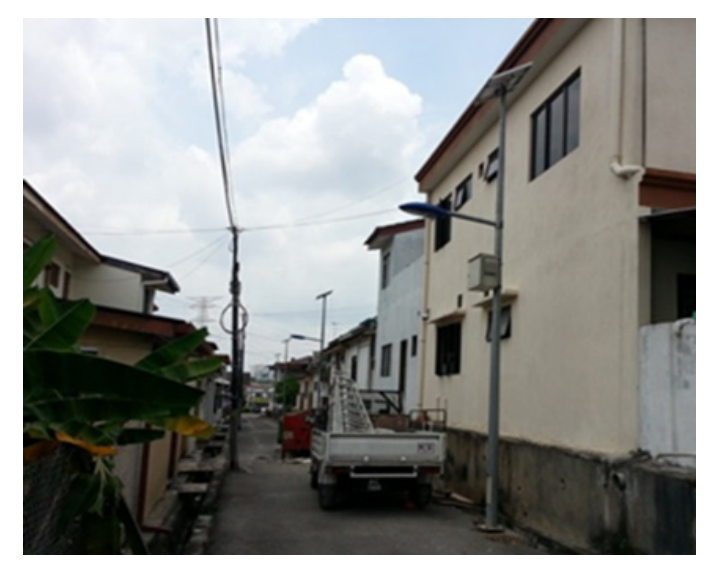

Figure 12. LED light post installation by Petaling Jaya Municipal Council (MPPJ) to illuminates back lane during night time. (Source: Author, 2013) 
Table 2. Back lanes aspects; safety, infrastructure and utility, services \& maintenance and comfort \& health

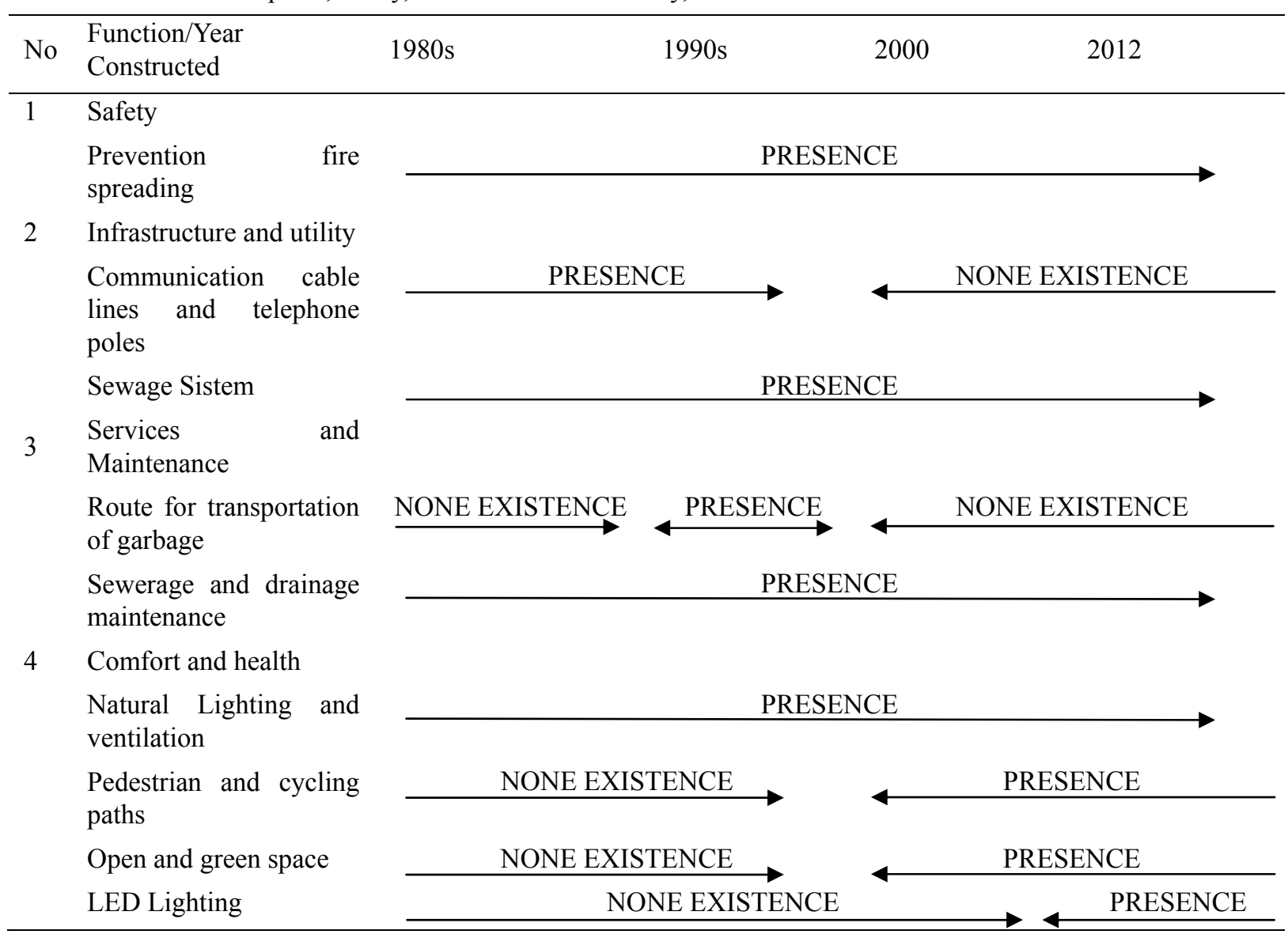

The above Table 2 reiterate four aspects of changes in physical elements in back lanes through four decades of terrace housing development in Malaysia.

\section{Conclusion}

Typology and design of back lane in terraced housing evolved since its existence in Malaysia. Although the overall design concept inspired from Georgian architecture in England during the Industrial Revolution of the $19^{\text {th }}$ century, in Malaysia it developed and experienced changes in terms of its physical form and function based on global issues.

The existence of terraced housing back lanes in developed countries in United States and United Kingdom are almost forgotten and neglected. Obviously the situation contradicts in Malaysia urbanization scenario. Back-lane of terrace housing in Malaysia had undergone evolution throughout local urbanization development for more practical socio-space function. Sustainable living, Garden City and Safe City Programme directly influence back-lane design and role. Site based observations conducted and discovered variations of design back lane on changes in element built differs as in 1980s on six aspects; road width, green and landscaping, drainage conditions, construction of pavement material, infrastructure \& maintenance and safety. The six aspects evolved due to several factors; safety, health and comfort. The additional green elements and landscaping has been discussed in the paper are in some way accord with the developer financial ability aspect and exclusivity of its location.

Variations of the design and functionality create confusion, numerous activities and problems identified at mostly terrace housing residents. In 2012 the Department of Town and Country Planning under the supervision of the Ministry of Housing and Local Government (JPBD) taking serious action and drafted Back-Lane Guidelines in the mid of 2012 principally for developers and urban planners. The guidelines set as regulation reference in designing an ideal back-lane for sustainable terrace housing scheme in the future without forfeiting the safety and health aspects of the dwellers and residential community. Back lanes as seen as underused and hardly maintained yet become favourite access to thieves and robberies. Thus, research on the effectiveness of 
back-lane design in terrace houses towards safety and health issues to be further investigated and analyzed towards achieving sustainable living in urban environment. In view to this, back-lane shall not be look as wasteful and neglected area but it should be remarkably design as spatially defined spaces to urban dwellers.

\section{Acknowledgements}

The authors are grateful to UKM, Malaysia for providing financial support to conduct this research.

\section{References}

Armitage, R., \& Smithson, H. (2007). Alley-Gating Revisited: The Sustainability Of Residents Satisfaction? Internet Journal of Criminology. Retrieved from http://www.internetjournalofcriminology.com

Beasley, E. (1997). The Alleys and Back buildings of Galveston-Architectural and Social History. Houston: Rice University Press.

Clay, G. (1980). Close-up: How to Read the American City (2nd ed.). United States America: Chicago Press.

Cook, E. (1998). Lanes in the American Landscape. Paper for American Landscape History course. Center for Environmental Studies, Williams College.

Corbett, T. (2002). The Alley: A Backstreet History of New York's Communities. Voices, (28).

Department of the Environment. (2001). Planning Policy Statement 7 (PPS 7) Quality Residential Environments. United Kingdom.

Federal Department of Town and Country Planning Peninsular Malaysia (JPBD), Ministry of Housing and Local Government. (2012). Back Lane Planning Guidelines 025 (Draft2012).

Federal Department of Town and Country Planning Peninsular Malaysia (DTCP), Ministry of Housing and Local Government. (2010). Crime Prevention through Environmental Design (CPTED): Implementation Guide.

Frampton, K. (1992). Modern Architecture: A Critical History (3rd ed.). London: Thames and Hudson.

Gua, H., \& Ryan, C. (2007). Place attachment, identity and community impacts of tourism-the case of a Beijing Hutong. Tourism Management, 29(2008), 637-647.

Gumus, E. (2004). Crime in urban areas: An empirical investigation. Akdeniz I. I. B. F. Dergisi, (7), 98-109.

Hess, P. M. (2008). Fronts and Backs: The Use of Streets, Yards, and Alleys in Toronto-Area New Urbanist Neighborhoods. Journal of Planning Education and Research, (28), 196. http://dx.doi.org/10.1177/0739456X08321799

Hui, L. J. S. (2003). Analysis on the Internal Structure of Fangli Units of Chang'an in Tang Dynasty. City Planning Review, 2003-2010

Ibrahim, M. H., Jahi, J. M., Hadi, A. S., \& Ariffin, K. (2011). Menyingkap perkembangan perbandaran Ipoh menjadi sebuah bandaraya. SARI: Jurnal Alam dan Tamadun Melayu, 29(2), 149-166.

James, P., \& Thorpe, N. (1995). Ancient Inventions. Great Britain: Michael O’Mara Books Limited.

Ju, S. R., Zaki, S. A., \& Yun, K. C. (2011). Contextual Modernization; New Town Planning in Petaling Jaya, of Malaysia. Journal of Asian Architecture and Building Engineering, 10(1), 93-100. $\mathrm{http}: / / \mathrm{dx}$. doi.org/10.3130/jaabe.10.93

Kostof, S. (1992). The city assembled: the elements of urban form through history. London: Thames and Hudson.

Liang, L. (1996). Lembaran sejarah gemilang: Hubungan Empayar Melaka-Dinasti Ming abad ke-15. Malaysia: Universiti Kebangsaan Malaysia.

Martin, M. (2000). Endangered Landscapes: Residential Alley Transformations. APT Bulletin, 31(4), 39-45. http://dx.doi.org/10.2307/1504675

Martin, M. (2002). The case for residential back-alleys: A North American Perspective. Journal of Housing and the Built Environment, 17(2), 145-171. http://dx.doi.org/10.1023/A:1015692824140

Mead, A. (2007, October 18). Contemporary Terraced House Types. Architects Journal, 25-45.

Muthesius, S. (1982). The English Terraced House. New Haven; Yale University Press.

Newella, J. P., Seymourb, M., Yee, T., Renteria, J., Longcore, T., Wolch, J. R., \& Shishkovsky, A. (2012). Green Alley Programs: Planning for a sustainable urban infrastructure? Cities, (31), 144-155. 
Nolan, S. (2013, January 4). Britain's ghost town: No cars and rows and rows of boarded-up terraced houses-can $£ 10 \mathrm{~m}$ bring dying Accrington community back to life? Daily Mail. Retrieved from http://www.dailymail.co.uk/news/article-2256796/Rows-boarded-terraced-houses-Accrington-brought-life10m-revamp.html

Robert, N. H. (2000). Asphalts in Road Construction. London: Thomas Telford.

Shafii, F. (2006, September). Achieving Sustainable Construction in the Developing Countries of South East Asia Proceedings of the 6th Asia-Pacific Structural Engineering and Construction Conference (APSEC 2006) (pp. 5-6). Kuala Lumpur, Malaysia.

Shahminan, R. N. R. (2007). Kajian Tipologi Rumah Kedai Awal Era Belanda Di Bandar Melaka: Sumbangan Kepada Bidang Pemuliharaan Di Malaysia. Master's thesis, Universiti Sains Malaysia.

Yahaya, F. H. (2005). Kemunculan Penyakit Berjangkit dan Kesannya Terhadap Manusia di Malaysia. Sari, 23, 153-168.

Zelinka, A., \& Beattie, W. (2003). How to turn alleys into allies. Planning Magazine, 69(10), 25.

\section{Copyrights}

Copyright for this article is retained by the author(s), with first publication rights granted to the journal.

This is an open-access article distributed under the terms and conditions of the Creative Commons Attribution license (http://creativecommons.org/licenses/by/3.0/). 